\title{
Wybrane modele rachunku kosztów jakości i ich zastosowanie
}

\section{Selected Models of Quality Costs Calculation and their Application}

\begin{abstract}
Streszczenie: Głównym celem artykułu jest przedstawienie najważniejszych modeli rachunku kosztów jakości dla przedsiębiorstw oraz ich funkcji. Ponadto autor podejmuje próbę oceny zaprezentowanych modeli pod kątem możliwości ich zastosowania w różnych typach organizacji. W pierwszej części rozważania skupiają się na strukturalnych modelach kosztów jakości. Drugi punkt dotyczy charakterystyki modeli opartych na działaniach. W trzeciej części zawarte są dotychczasowe zastosowania modeli rachunku kosztów jakości. Obiekt badań stanowi rachunek kosztów jakości, który w praktyce gospodarczej wykorzystywany jest jako narzędzie stosowane do pomiaru i optymalizacji kosztów jakości. W pracy przeprowadzono analizę piśmiennictwa naukowego z zakresu rachunkowości, zarządzania jakością oraz zastosowano metody indukcji i dedukcji. Globalizacja oraz rozwój naukowo-techniczny spowodowały, że w centrum uwagi przedsiębiorców znalazł się klient i jego potrzeby. Aby sprostać wymaganiom i potrzebom konsumentów, poprzez oferowanie produktów/usług najwyższej jakości, przedsiębiorstwa coraz większą uwagę skupiają na stosowaniu rachunku kosztów jakości. Tradycyjne modele rachunku kosztów jakości straciły na znaczeniu, rośnie natomiast zainteresowanie modelami opartymi na działaniach oraz postrzegającymi produkt/usługę z perspektywy konsumenta, zwiększa się także rola takich modeli.
\end{abstract}

\begin{abstract}
The main aim of the article is to present the most important models of quality costs calculation for companies and their functions. Furthermore, the author attempts to evaluate the presented models in terms of their applicability in various types of organisations. The first part of the discussion focuses on structural quality costs models. The second point concerns the characteristics of action-based models. The third part contains the current uses of models of quality costs calculation. The research object is a quality costs calculation, which in economic practice is used as a tool for measure and optimize quality costs. The paper provides the analysis of the scientific literature in the field of accounting, quality management and applies methods of induction and deduction. Globalisation and the development of science and technology have placed the customer and his needs in the centre of entrepreneurs' attention. To meet the needs and demands of consumers by offering the highest quality products/services, companies are focusing on the use of quality costs calculation. Traditional models of quality costs calculation have become less important, but the interest and role of models based on the activities and product/service perceptions of the consumer are growing.
\end{abstract}

Słowa kluczowe: jakość; koszty jakości; model; rachunek kosztów jakości

Keywords: model; quality; quality costs; quality costs calculation 
Otrzymano: 11 czerwiec 2018

Received: 11 June 2018

Zaakceptowano: 11 czerwca 2018

Accepted: 11 June 2018

\section{Sugerowana cytacja/Suggested citation:}

Sadkowski, W. (2017). Wybrane modele rachunku kosztów jakości i ich zastosowanie. Przedsiębiorczość - Edukacja [Entrepreneurship - Education], 14, 221-233. DOI: 10.24917/20833296.14.16

\section{Wstęp}

Globalizacja oraz rozwój naukowo-techniczny przyczyniły się do wzrostu zainteresowania przedsiębiorców problematyką jakości. W centrum uwagi znalazł się klient i jego potrzeby. Aby sprostać wymaganiom i potrzebom konsumentów poprzez oferowanie produktów/usług najwyższej jakości, przedsiębiorstwa coraz większą uwagę zwracają na stosowanie rachunku kosztów jakości.

Tradycyjne modele rachunku kosztów jakości straciły na znaczeniu, rośnie natomiast zainteresowanie modelami opartymi na działaniach oraz postrzegającymi produkt/usługę z perspektywy konsumenta, zwiększa się także rola takich modeli.

Celem artykułu jest przedstawienie najważniejszych modeli rachunku kosztów jakości dla przedsiębiorstw oraz ich zastosowań.

W pierwszym podrozdziale zebrane zostały najważniejsze strukturalne modele kosztów jakości. Druga część artykułu zawiera ogólną charakterystykę modeli rachunku kosztów jakości opartych na działaniach. W ostatnim podrozdziale autor prezentuje dotychczasowe zastosowania modeli rachunku kosztów jakości.

W artykule zostały wykorzystane studia literaturowe z zakresu rachunkowości i zarządzania jakością. Ponadto autor zastosował metody indukcji i dedukcji.

\section{Strukturalne modele rachunku kosztów jakości}

Strukturalne modele kosztów jakości pojawiły się w literaturze przedmiotu wraz z postępującymi zmianami społeczno-gospodarczymi. Pierwsze formalne modelowe ujęcia datowane są na przełom lat 50. i 60. ubiegłego wieku. Miały one służyć do pomiaru efektywności zarządzania przedsiębiorstwem w obszarze jakości. Wywodzą się z amerykańskiej praktyki gospodarczej, a kolejne modele, będące ich kontynuacją, zostały przygotowane w krajach europejskich.

Najbardziej charakterystyczne modele strukturalne rachunku kosztów jakości to amerykański model A.V. Feigenbauma, model ASQC (American Society for Quality Control), brytyjski model J. Banka oraz model E. Kindlarskiego.

Model kosztów jakości A.V. Feigenbauma, rozpropagowany w Japonii przez książkę Total Quality Control, jest rozwinięciem myśli W. Massera (kategoryzacja kosztów jakości) i zawiera działania związane z prewencją, oceną i ze skutkami błędów. Do jego opracowania wykorzystana została również koncepcja ekonomicznej jakości J.M. Jurana. Koszty w tym modelu zostały podzielone na koszty sterowania jakością i koszty braku sterowania jakością, nazywane kosztami błędów wewnętrznych i zewnętrznych. Koszty sterowania jakością to koszty prewencji i koszty oceny, które są traktowane jako nakłady inwestycyjne. Z kolei koszty błędów to straty (Sadkowski, Kołodziejczuk, 2017). 
Model A.V. Feigenbauma dedykowany jest przedsiębiorstwom masowej produkcji. Jakość powinna być rozpatrywana w kolejnych fazach procesu realizacji produktu - od pomysłu aż do likwidacji zużytego wyrobu. Dlatego pojawiły się w nim takie elementy, jak: planowanie jakości, rozwój systemów jakości czy szkolenia, które zaliczane są do działań prewencyjnych. Masowość produkcji powoduje, że przeważają działania kontrolne nad prewencyjnymi (Zymonik, Hamrol, Grudowski, 2013).

A.V. Feigenbaum zwrócił również uwagę na nowy w tamtych czasach instrument prawny w kosztach błędów - productliability, czyli odpowiedzialność za jakość produktu/usługi, która obejmuje koszty spowodowane przez niebezpiecznie wadliwe produkty/ usługi (Zymonik, 2003). Wszystkie koszty tego modelu zebrane zostały w tabeli 1.

Tab. 1. Model strukturalny kosztów jakości A.V. Feigenbauma

\begin{tabular}{|c|c|}
\hline \multicolumn{2}{|c|}{ Koszty sterowania jakością } \\
\hline koszty prewencji & koszty oceny \\
\hline $\begin{array}{l}\text { - planowanie jakości } \\
\text { - kontrola procesu } \\
\text { - projektowanie wyposażenia informującego } \\
\text { o jakości produktu i procesu } \\
\text { - szkolenia w zakresie jakości } \\
\text { - weryfikowanie projektów produktu } \\
\text { - zarządzanie systemem jakości i jego rozwój } \\
\text { - pozostałe koszty zapobiegania błędom }\end{array}$ & $\begin{array}{l}\text { - } \text { badanie i kontrola zakupionych materiałów } \\
\text { - } \text { badanie laboratoryjne materiałów } \\
\text { wejściowych } \\
\text { - } \text { kontrola sprawności wyposażenia } \\
\text { do badania i pomiarów } \\
\text { - czynności badawcze i kontrolne (czas) } \\
\text { - ocena spełnienia wymagań technicznych } \\
\text { wyrobu (czas) } \\
\text { - sortowanie partii wyrobów na zgodne } \\
\text { i niezgodne z wymaganiami } \\
\text { - samokontrola (czas) } \\
\text { - przygotowanie sprzętu pomiarowo- } \\
\text {-kontrolnego (czas) } \\
\text { - materiały do badań i kontroli } \\
\text { - } \text { audity jakości (czas) } \\
\text { - ocena prowadzona przez zewnętrzne } \\
\text { jednostki badawcze i kontrolne } \\
\text { - eksploatacja wyposażenia informującego } \\
\text { o jakości produktu i procesu } \\
\text { - czynności, których wynikiem jest } \\
\text { dopuszczenie produktu do eksploatacji } \\
\text { - badania próbne produktu w eksploatacji }\end{array}$ \\
\hline \multicolumn{2}{|c|}{ Koszty braku sterowania jakością } \\
\hline koszty błędów wewnętrznych & koszty błędów zewnętrznych \\
\hline $\begin{array}{l}\text { - odpady } \\
\text { - poprawki } \\
\text { - materiały do poprawek } \\
\text { - zaangażowanie pracowników } \\
\text { w rozwiązywanie problemów jakości (czas) }\end{array}$ & $\begin{array}{l}\text { - reklamacje gwarancyjne } \\
\text { - reklamacje pozagwarancyjne } \\
\text { - odpowiedzialność za produkt } \\
\text { - wycofanie produktu z rynku } \\
\text { - wycofanie produktu z eksploatacji }\end{array}$ \\
\hline
\end{tabular}

Źródło: Zymonik, Hamrol, Grudowski (2013)

Kolejnym istotnym modelem strukturalnym kosztów jakości jest - przygotowany na zlecenie rządu USA - ASQC. Powstał on w wyniku narastającego niezadowolenia z jakości dostarczanych surowców, materiałów, elementów kooperacyjnych dla tzw. wielkich zleceniodawców. Ich żądania skierowane do swoich dostawców dotyczyły działań projakościowych, które powinny obejmować cały proces realizacji wyrobu, od złożenia 
zamówienia na materiały i elementy kooperacyjne, aż do momentu wysyłki gotowego wyrobu. Konieczne było określenie poziomu wadliwości produktów i elementów składowych, a także wysokości kosztów jakości.

W odpowiedzi na potrzeby amerykańskiego przemysłu w opublikowanej przez Komitet Kosztów Jakości ASQC broszurze QualityCost - What and How, zaprezentowany został strukturalny model kosztów jakości (tab. 2), w którym powołano się na model kosztów Feigenbauma (ASQC, 1971). Koszty jakości zostały w nim podzielone na koszty działalności zapobiegawczej, koszty oceny jakości i koszty niskiej jakości (wewnętrzne i zewnętrzne). Ich struktura została ukierunkowana na produkcję masową i wielkoseryjną (Weinstein, Vokurka, Graman, 2009). Rozbudowana została prewencja, dominują braki naprawialne i nienaprawialne, preferowane są działania kontrolne, które mają umożliwić wychwycenie wadliwych produktów i nie dopuścić do ich przedostania się poza przedsiębiorstwo.

Tab. 2. Strukturalny model kosztów jakości według ASQC

\begin{tabular}{|c|l|}
\hline \multicolumn{1}{|c|}{ Koszty prewencji } & \multicolumn{1}{c|}{ Koszty oceny jakości } \\
\hline - planowanie jakości produktu i sterowanie & - próby i kontrola materiałów wejściowych \\
jakością produkcji: prace związane & - badania laboratoryjne materiałów \\
z planowaniem jakości, mające charakter & wejściowych \\
techniczny; prace wdrożeniowe, związane & - próby i kontrola wyrobów \\
z planowaniem jakości i procedurami & - prace pomocnicze związane z próbami \\
dotyczącymi sterowania jakością & - organizacja prób i kontroli \\
- projektowanie metod pomiarów urządzeń & - okresowe komisyjne kontrole jakości \\
pomiarowo-kontrolnych & - atestowanie produktów przez zewnętrzne \\
- planowanie jakości przez inne komórki & instytucje \\
funkcjonalne (poza działem sterowania & - konserwacja i kalibrowanie przyrządów do \\
jakością) & prób i kontroli \\
- szkolenia pracowników w zakresie jakości & - analizowanie wyników prób i kontroli \\
- inne koszty związane z działalnością & - prace związane z badaniami wyrobów we \\
zapobiegawczą & własnym zakresie i dopuszczeniem ich do \\
& produkcji \\
& - ocena jakości materiałów i części \\
& w magazynach \\
\hline Koszty błędów wewnętrznych & Koszty błędów zewnętrznych \\
\hline - braki nienaprawialne & - reklamacje klientów \\
- przeróbki i naprawy & - serwis posprzedażny \\
- identyfikowanie przyczyn zakłóceń & - przeróbki zwróconych wyrobów \\
procesu wytwórczego & - naprawy zwróconych wyrobów \\
- powtórna kontrola i próby & - wymiana wyrobów w ramach gwarancji \\
- prace dodatkowe związane & - błędy techniczne \\
z dostosowaniem materiałów do wymagań & - błędy związane z instalowaniem wyrobów \\
jakościowych & \\
- ponowne sortowanie odrzutów & \\
- przekwalifikowanie wyrobów do niższych & \\
klas jakości & \\
\hline
\end{tabular}

Źródło: Zymonik, Hamrol, Grudowski (2013)

Model ASQC modyfikowano co 10 lat, struktura kosztów nie uległa zmianie, ewolucją objęte zostały objaśnienia do działań prewencyjnych. Proponowane zmiany nie dotyczyły rozwiązań ukierunkowanych na doskonalenie organizacji i poprawę jakości zarządzania przedsiębiorstwem, a wiązały się ze sposobami, za pomocą których marketing, 
projektowanie, zapewnienie jakości i zarządzanie firmą mogą wpłynąć na ograniczenie kosztów oceny i niskiej jakości (Zymonik, 2003).

Europa zainteresowała się kosztami jakości na obradach szczytu paryskiego w październiku 1972 roku. Do tego czasu państwa europejskie pozostawały bez rozwiązań w sprawie ochrony konsumenta przed wadliwymi produktami. Międzynarodowe powiązania korporacyjne między Wielką Brytanią i USA oraz amerykański model ASQC wywarły wpływ na powstanie w Brytyjskim Instytucie Normalizacji (BSI) i opublikowanie w 1981 roku normy BS 6143, która jest modyfikowana co kilka lat (Zymonik, Hamrol, Grudowski, 2013).

Zapoczątkowany boom na usługi w latach 80. XX w. wymógł stworzenie odpowiednich modeli kosztów jakości dla tego typu przedsiębiorstw. Wypracowane w sferze produkcji dobre standardy, mogły być z powodzeniem wykorzystane w sferze usługowej. Błędy popełniane w Wielkiej Brytanii w usługach, takich jak: administracja rządowa, ochrona zdrowia, sądownictwo, zostały zanalizowane przez J. Banka. Każdą z tych organizacji potraktował on jako zbiór procesów i odniósł do nich koszty jakości. Badania te oraz model procesu ujęty w normie BS 6143 posłużyły J. Bankowi do stworzenia nowego modelu (tab. 3), w którym rozróżnił trzy podstawowe kategorie kosztów: zgodności, niezgodności oraz utraconych korzyści (Bank, 1996).

Tab. 3. Model strukturalny kosztów jakości Johna Banka

\begin{tabular}{|c|c|c|c|}
\hline \multicolumn{4}{|c|}{ Koszty zgodności } \\
\hline \multicolumn{2}{|c|}{ koszty profilaktyki } & \multicolumn{2}{|r|}{ koszty oceny } \\
\hline \multicolumn{2}{|c|}{$\begin{array}{l}\text { - szkolenie pracowników } \\
\text { - opracowanie programów jakości } \\
\text { uświadamiających rolę jakości } \\
\text { w przedsiębiorstwie } \\
\text { - planowanie i organizowanie warsztatów } \\
\text { jakości oraz kół jakości }\end{array}$} & \multicolumn{2}{|c|}{$\begin{array}{l}\text { - inspekcje i kontrole } \\
\text { - przeglądy dokumentów }\end{array}$} \\
\hline \multicolumn{4}{|c|}{ Koszty niezgodności } \\
\hline $\begin{array}{l}\text { koszty błędów } \\
\text { wewnętrznych }\end{array}$ & \multicolumn{2}{|c|}{$\begin{array}{c}\text { koszty } \\
\text { błędów zewnętrznych }\end{array}$} & $\begin{array}{c}\text { koszty przekroczenia } \\
\text { wymagań }\end{array}$ \\
\hline $\begin{array}{l}\text { - odrzuty } \\
\text { - poprawki }\end{array}$ & \multicolumn{2}{|c|}{$\begin{array}{l}\text { - koszty gwarancji } \\
\text { - poprawki w produktach } \\
\text { - korygowanie błędnych } \\
\text { faktur } \\
\text { - nieplanowane koszty } \\
\text { związane z obsługą }\end{array}$} & $\begin{array}{l}\text { - zbędne dokumenty lub ich } \\
\text { kopie } \\
\text { - niepotrzebne raporty } \\
\text { - zbyt szczegółowe analizy } \\
\text { - zbędne delegacje do } \\
\text { klienta }\end{array}$ \\
\hline \multicolumn{4}{|c|}{ Koszty utraconych korzyści } \\
\hline $\begin{array}{l}\text { - utrata przychodów } \\
\text { wynikająca z odejścia } \\
\text { dotychczasowych klientów }\end{array}$ & \multicolumn{2}{|c|}{$\begin{array}{l}\text { - utrata potencjalnych } \\
\text { klientów }\end{array}$} & $\begin{array}{l}\text { - utrata potencjalnego } \\
\text { wzrostu przychodów ze } \\
\text { sprzedaży, wynikająca } \\
\text { z dostarczenia klientom } \\
\text { produktów niezgodnych } \\
\text { Z ich wymaganiami }\end{array}$ \\
\hline
\end{tabular}

Źródło: Zymonik (2003)

Kosztami zgodności są działania związane z profilaktyką (czynności, które mają zapobiec powstawaniu błędów - programy jakości) oraz ocenom, którym autor poświęca 
mało uwagi. Do kosztów niezgodności należą koszty błędów wewnętrznych i zewnętrznych oraz koszty przekroczenia wymagań. Rozbudowana biurokracja, która marnotrawi zasoby materialne i niematerialne w niepotrzebnych dokumentach, raportach, analizach czy delegacjach, znajduje swoje miejsce w kosztach niezgodności, które są dosyć powierzchownie omówione w tym modelu.

J. Bank wprowadza nowy rodzaj kosztów niezgodności, które wiążą się z przekroczeniem wymagań jakościowych. Charakterystycznym elementem jego modelu są koszty utraconych korzyści, które dotyczą między innymi wycofanych zamówień w związku ze zbyt wolną realizacją zlecenia, zakupów produktów u konkurentów spowodowane brakiem ich w firmie w danej chwili, sprzedawaniem klientom produktów, które nie spełniają ich potrzeb (Bank, 1996).

Wartościowy model kosztów jakości opracowany przez E. Kindlarskiego (tab. 4) rozbudowuje ich strukturę o koszty badania poziomu jakości, dzieląc je na cztery główne kategorie: osobowe, energii, materiałowe oraz badań (zewnętrzne) (Gawron-Zimon, 2012).

Tab. 4. Model strukturalny kosztów jakości E. Kindlarskiego

\begin{tabular}{|c|c|}
\hline \multicolumn{2}{|c|}{ Koszty niskiego poziomu jakości } \\
\hline wewnętrzne & zewnętrzne \\
\hline $\begin{array}{l}\text { - koszty pozyskania półproduktów niskiej } \\
\text { jakości } \\
\text { - prace naprawcze wewnątrz organizacji } \\
\text { - kontrola wadliwych produktów } \\
\text { - praca w nadgodzinach }\end{array}$ & $\begin{array}{l}\text { - obsługa reklamacji } \\
\text { - kary lub rabaty } \\
\text { - koszty napraw u klienta }\end{array}$ \\
\hline \multicolumn{2}{|c|}{ Koszty badania poziomu jakości } \\
\hline osobowe & materiałowe \\
\hline $\begin{array}{l}\text { - kontrola wstépna zakupionych } \\
\text { półproduktów } \\
\text { - utrzymanie w optymalnym stanie urządzeń } \\
\text { kontrolno-pomiarowych } \\
\text { - kontrola jakości na etapie produkcji } \\
\text { - odbiór końcowy } \\
\text { - badanie niezawodności }\end{array}$ & - konserwacja aparatury i oprzyrządowania \\
\hline Energii & Badań (zewnętrzne) \\
\hline koszty zużytej energii & koszty ubezpieczeń, atestacji i certyfikacji \\
\hline \multicolumn{2}{|c|}{ Koszty zapobiegawcze } \\
\hline $\begin{array}{l}\text { - koszty działu kontroli } \\
\text { - koszty budowy i zakupu urządzeń pomiarow } \\
\text { - koszty szkolenia personelu odnośnie jakości } \\
\text { - koszty badania stanu technicznego oraz kon }\end{array}$ & erwacji urządzeń \\
\hline
\end{tabular}

Źródło: Gawron-Zimon (2012)

Przedstawione modele strukturalne kosztów jakości wynikają z kształtowania się na przestrzeni lat ich rachunku kosztów i korzyści. Charakterystycznymi ich elementami są koszty związane z działaniami prewencyjnymi, badaniami i kontrolą oraz skutkami powstałych błędów. Różnice w tych modelach wiążą się z zakresem, pomimo tego, że najczęściej koszty jakości odnoszone są do faz produkcyjnych. Tylko J. Banka wprowadza koszty zgodności i niezgodności. 
Przedstawione modele struktury kosztów jakości nie nadążają za szybkim postępem w dziedzinie nauki i techniki. Elementy kosztów związanych z jakością są eksponowane w sposób wybiórczy. Konieczne stało się przygotowanie nowych propozycji rachunku kosztów jakości.

\section{Modele rachunku kosztów jakości oparte na działaniach}

Tradycyjne modele kosztów jakości nie sprawdziły się. W niewielkim stopniu uwzględniają dobro klienta oraz jego interes ekonomiczny. Przestały być wystarczające dla przedsiębiorstw, które wdrażając system rachunku kosztów jakości liczą na poprawę efektywności działań projakościowych.

Osiągnięcie odpowiedniego poziomu efektywności na każdym badanym poziomie organizacyjnym, procesowym oraz na stanowisku pracy jest możliwe poprzez wykorzystanie odpowiednich miar wejścia i wyjścia. Nowe modele kosztów jakości oparte na działaniach pozwalają uzyskać zamierzone rezultaty (Zymonik, 2003).

Rachunek kosztów jakości oparty na działaniach prezentują modele kosztów jakości przygotowane przez J.M. Jurana, A.M. Schneidermana oraz R.S. Kaplana.

Podstawą modelu J.M. Jurana jest koncepcja odnosząca się do procesów rozumianych w szerokim ujęciu - procesów podstawowych i pomocniczych. Projektowanie, wytwarzanie, dokumentowanie, obsługa klienta są uniwersalne i zawsze składają się z trzech elementów (Juran, 1989):

- planowania jakości (identyfikacja klienta, którym - wg Jurana - jest każdy, kto ma kontakt z procesem - klienci „wewnętrzni” i „zewnętrzni”; najważniejsze to rozpoznanie potrzeb klientów, będące podstawą do przygotowania charakterystyk jakości i zdefiniowania celów jakościowych oraz środków, które pomogą je osiągnąć);

- sterowania jakością (zidentyfikowanie i zmierzenie krytycznych elementów wyrobu i procesu oraz porównanie ich ze standardami; w przypadku wystąpienia odchyleń konieczne jest podjęcie działań korygujących i zapobiegawczych; sterowanie jakością powinno się odbywać na możliwie najniższym szczeblu zarządczym przedsiębiorstwa; konieczne jest podjęcie szkoleń związanych ze sposobem zbierania danych i technik rozwiązywania problemów jakościowych);

- doskonalenia jakości (zrozumienie konieczności usprawnienia procesów oraz opracowanie odpowiednich projektów działań; za doskonalenie jakości odpowiada zespół, który ma zdiagnozować problem, ustalić jego przyczyny oraz przygotować środki zaradcze, a także mechanizmy służące do sterowania nowym procesem).

Dla J.M. Jurana punktem wyjściowym w traktowaniu każdego procesu jako triady, czyli planowania, sterowania i doskonalenia, stało się zróżnicowanie błędów na chroniczne i sporadyczne. Rozwiązywanie problemów jakościowych powinno się wiązać z projektem procesu, który przyczyni się do usunięcia błędów chronicznych.

W modelu J.M. Jurana, najważniejsze są działania badawcze i kontrolne, a działań prewencyjnych jest stosunkowo niewiele. Jakość jest postrzegana pod kątem właściwości i cech produktu, które zostały ujęte w dokumentacji technicznej. W XX w. miarą sukcesu przedsiębiorstwa było wyprodukowanie wyrobu zgodnego z ustaloną dokumentacją produktu (Superville, Gupta, 2001).

J.M. Juran posługuje się w swoim modelu kosztów jakości pojęciem „akceptowalnego poziomu wadliwości”. Uważa, że niemożliwe jest osiągnięcie 100\% zgodności 
z wymaganiami, przez co rzeczywisty poziom kosztów jakości może być dużo wyższy od optymalnego, ale nadal opłacalny dla przedsiębiorstw produkujących (Juran, 1989). Najważniejsze elementy wyróżniające model J.M. Jurana zostały zestawione w tabeli 5.

Tab. 5. Kluczowe elementy tradycyjnego modelu kosztów jakości J. M. Jurana opartego na działaniach

\begin{tabular}{|l|l|}
\hline \multicolumn{1}{|c|}{ Element } & \multicolumn{1}{c|}{ Opis } \\
\hline $\begin{array}{l}\text { Jakość jako element planowania } \\
\text { strategicznego }\end{array}$ & $\begin{array}{l}\text { Koncepcja związana z produkcją masową lat 40. i } 50 . \\
\text { ubiegłego wieku }\end{array}$ \\
\hline Każde działanie jest procesem & Procesy są zakłócane przez wiele czynników \\
\hline Uniwersalność procesów & $\begin{array}{l}\text { W każdym procesie wyróżniamy trzy elementy: } \\
\text { planowanie, sterowanie jakością i doskonalenie jakości }\end{array}$ \\
\hline System zarządzania przedsiębiorstwem & $\begin{array}{l}\text { Związany tylko z błędami chronicznymi, mającymi } \\
\text { charakter ciągły, i słabo zauważalnymi }\end{array}$ \\
\hline Błędy chroniczne & $\begin{array}{l}\text { To część każdego procesu. Akceptowalne na pewnym } \\
\text { poziomie, ponieważ niemożliwe jest poprawne } \\
\text { określenie wszystkich zmiennych w projekcie procesu }\end{array}$ \\
\hline Działania projakościowe & Mają charakter korygujący lub zapobiegający \\
\hline Działania korygujące błędy & $\begin{array}{l}\text { Przypisane do uczestników procesu, zadania } \\
\text { zapobiegające błędom podejmowane przez } \\
\text { specjalistów }\end{array}$ \\
\hline Szkolenia z zarządzania jakościowego & $\begin{array}{l}\text { Dla wszystkich pracowników (zarządzających } \\
\text { i zarządzanych) }\end{array}$ \\
\hline Akceptowalny poziom wadliwości & $\begin{array}{l}\text { Brak możliwości osiągnięcia 100\% zgodności } \\
\text { z wymaganiami jakościowymi ujętymi w dokumentacji } \\
\text { technicznej produktu }\end{array}$ \\
\hline
\end{tabular}

Źródło: opracowanie własne na podstawie: Zymonik (2003)

Panujące w latach 80. XX w. warunki społeczno-gospodarcze przyczyniły się do zmiany podejścia do jakości. W centrum zainteresowania zaczęto stawiać klienta i jego wymagania jakościowe dotyczące właściwości i cech produktu. Udoskonaleniu uległ cały proces rozwoju wyrobu, który rozpoczynał się na pomyśle i był realizowany w pozostałych fazach: projektowaniu, produkcji, dystrybucji, sprzedaży, a także obsłudze klienta, i kończył się na użytkowaniu aż do momentu jego zniszczenia, które miało być przyjazne środowisku. Również pod kątem ekonomicznym jakość nabrała nowego wymiaru - połączenie z marketingiem, wymagania jakościowe dotychczas dostępne tylko na etapie produkcji, rozszerzone także na rynki i proces użytkowania.

W wyniku tych postępujących zmian model kosztów jakości zaprezentowany przez J.M. Jurana przestał być użyteczny. Konieczne stało się opracowanie nowej koncepcji kosztów jakości. Została ona przygotowana i opublikowana przez A.M. Schneidermana w 1986 roku, który podobnie jak J.M. Juran dąży do minimalizacji całkowitych kosztów jakości, traktowanych jako koszty zgodności i niezgodności z wymogami jakościowymi (Zymonik, 2003).

Jakości nie można już odnosić tylko do zgodności z dokumentacją techniczną, ale trzeba ją powiązać także ze spełnieniem oczekiwań klienta. Koncepcja A.M. Schneidermana znajduje zastosowanie podczas całego procesu rozwoju produktu. Wyjściowym punktem są wymagania klienta dotyczące jakości, które niejednokrotnie są trudne do zidentyfikowania. 
Model tego badacza opiera się na koncepcji bezbłędności, wywodzącej się od Lao Tsu i P. Crosby’ego, która koncentruje się na działaniach prewencyjnych. W gospodarce istnieje wiele instrumentów doskonalenia jakości, konieczny jest jedynie ich odpowiedni dobór w celu usprawnienia jakości. Optymalnym poziomem kosztów jakości jest sytuacja, gdy występuje pełna zgodność z potrzebami i oczekiwaniami klienta. Model ten nie zakłada akceptacji wadliwości (Scheiderman, 1986).

A.M. Schneiderman przeanalizował również warunki społeczno-gospodarcze XXI w.: nowe technologie, koncentrację na kliencie i silnie zaakcentowane znaczenie organizacji w zarządzaniu przedsiębiorstwem. Na podstawie swoich rozważań przygotował futurystyczny model kosztów jakości, w którym zdecydowanie przeważają działania prewencyjne. Jakość w tym ujęciu staje się powszechna i w pewnym momencie problem kosztów jakości znika.

R.S. Kaplan wykorzystał model kosztów jakości A.M. Schneidermana odnoszący się do pomiaru efektywności działań jakościowych w zarządzaniu organizacją i akcentujący wymagania jakościowe klienta. Podkreślił to słowami, „że organizacje muszą także poszukiwać usprawnień w zakresie jakości, czasu trwania czy wydajności określonych procesów wewnętrznych i obsługi klienta" (Kaplan, 2001: 131).

$\mathrm{Na}$ początku lat 80. uważano, że możliwe jest zmniejszenie liczby wadliwych produktów poprzez przesunięcie środków i kosztów, bez dodatkowych nakładów. W miarę upływu czasu przedsiębiorstwa przekonały się, że nie jest możliwe uzyskanie korzyści bez dodatkowych nakładów. Oznacza to, że przy zerowych kosztach nie da się osiągnąć efektywności, niezbędne są inwestycje. Potwierdza to R.S. Kaplan słowami: „aby zerwać owoce z wyższych gałęzi, trzeba [...] czasami kupić drabinę" (Kaplan, Cooper, 2000: 184). Dlatego jakość i jej wkład w sukces przedsiębiorstwa nie powinien skupiać się tylko na określaniu wielkości strat powstających w wyniku niezgodności z wymaganiami jakościowymi, ale powinien też dotyczyć dodatkowych kosztów, które przyczynią się do zapobiegania błędom.

Rachunek kosztów jakości oparty na działaniach zaprzecza strategii TQM mówiącej, że gdy poprawimy jakość, to wyniki finansowe przyjdą same. Brak identyfikacji procesów, które mają kluczowe znaczenie dla strategii przedsiębiorstwa, nieprzeprowadzenie pomiaru efektów i analizy kosztów - korzyści związanych z jakością, spowodują brak odpowiedzi na pytanie: „Czy przyczyną sukcesu podmiotu jest jakość?”. Z tych powodów tak ważne staje się dokonanie pomiaru efektywności jakości w obszarach: organizacji, procesu i stanowiska pracy (SedevichFons, 2012).

Informacje dotyczące działań jakościowych powinny się znaleźć w strategicznej karcie wyników. Wykorzystując odpowiednie miary, przy użyciu karty możliwe jest dokonanie oceny wpływu czynników na obecny i przyszły sukces firmy z czterech perspektyw: klienta, finansowej, wiedzy i rozwoju oraz procesów wewnętrznych. Każda z nich wiąże się bezpośrednio z kosztami jakości (ryc. 1).

Przedstawione modele rachunku kosztów jakości oparte na działaniach ewaluowały wraz z postępującym rozwojem naukowo-technicznym i gospodarczym XX w. Pogłębiająca się relacja między jakością i marketingiem oraz finansami spowodowała wykształcenie się pojęcia wartości konsumenckiej, czyli odnoszącej się do klienta, która jest zbiorem korzyści z nabywanego przez niego produktu.

Dotychczasowa tradycyjna formuła (cena sprzedaży = rzeczywiste koszty + zysk) straciła rację bytu, ponieważ odpowiedzialnością za wszystkie koszty produkcji danego dobra 
Ryc. 1. Koszty jakości w zarządzaniu przedsiębiorstwem wg Z. Zymonik

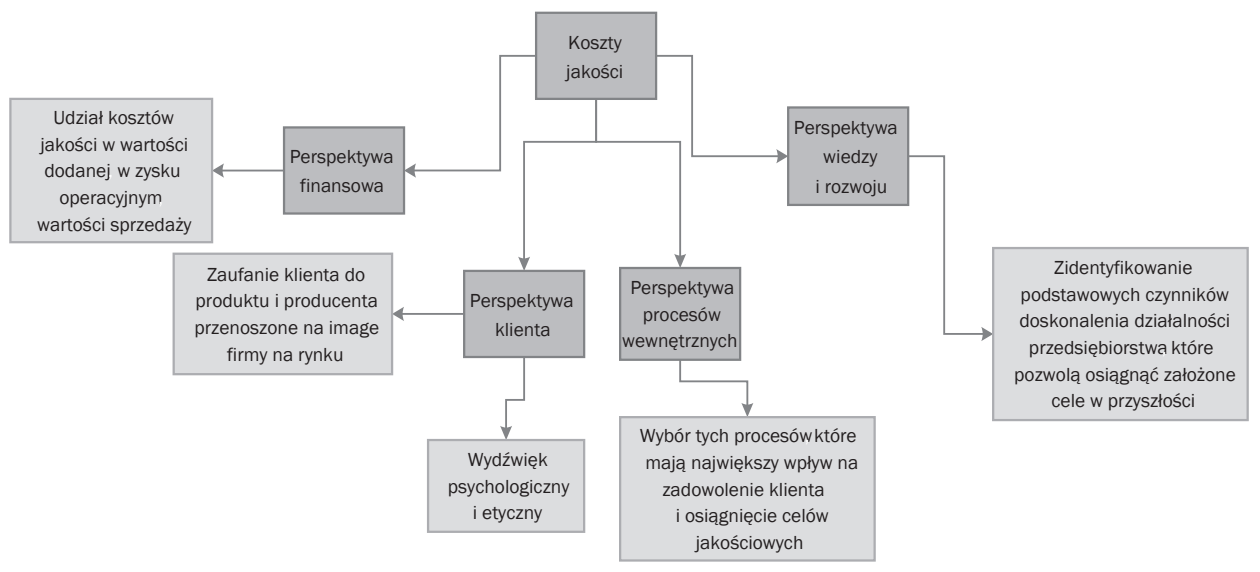

Źródło: opracowanie własne na podstawie Zymonik (2003: 173)

przez przedsiębiorstwo obarczano klienta. Płacenie przez konsumenta za coś, co nie ma dla niego wartości, czyli pokrywanie strat, które powstały w wyniku marnotrawstwa zasobów u producenta, jest już nie do przyjęcia. Najważniejsze stało się spojrzenie na produkt z perspektywy klienta i wydzielenie w firmie procesów wewnętrznych, które kreują jego wartość.

Proces kreowania wartości produktu niesie za sobą ryzyko pojawienia się błędów. Niezbędna jest ich identyfikacja, pomiar, aby można było dokonać korekty. Do realizacji tego celu wykorzystywane są mierniki kosztów jakości, nazywane parametrami przepływu błędów.

Zbadanie efektywności działań projakościowych wiąże się z porównaniem kosztów i korzyści jakości. Tradycyjne modele kosztów jakości nie sprawdzają się w nowej rzeczywistości, w której najważniejsze jest dobro klienta, jego zadowolenie i interes ekonomiczny.

\section{Dotychczasowe zastosowania rachunku kosztów jakości}

Rachunek kosztów jakości zaczyna odgrywać coraz większą rolę w świadomości przedsiębiorców i działalności przedsiębiorstw. Dwudziesty wiek przyniósł liczne modele tego rachunku, które zostały zaprezentowane przez autora w tym artykule. Wraz z rozwojem społeczno-gospodarczym i wzrostem w dziedzinie nauki i techniki pojawiały się coraz bardziej zaawansowane formy ujęcia kosztów jakości, które coraz lepiej dopasowywały się do rzeczywistości. Brak jednolitych zasad ewidencjonowania kosztów jakości spowodował, że ich ewidencja odbywa się w oparciu o obowiązujący w danym przedsiębiorstwie system rachunku kosztów.

Każdy z modeli kosztów jakości opartych na strukturze i działaniach pokazuje różne perspektywy postrzegania koszów jakości oraz ich pomiaru. Dostosowując działania projakościowe w przedsiębiorstwie do konkretnego modelu, należy mieć na uwadze, w jaki sposób klasyfikowane są koszty związane z jakością. Od właściwej ich identyfikacji zależy powodzenie wdrożenia rachunku kosztów jakości. Niezbędna jest zatem współpraca działu 
rachunkowości z działem jakości, dotycząca zidentyfikowania i pomiaru kosztów jakości.

Zmiana podejścia do jakości, która nastąpiła w latach 80. XX w., przyczyniła się do powstania modeli rachunku kosztów jakości opartych na działaniach. Koncepcja J.M. Jurana zdezaktualizowała się i w jej miejsce pojawiły się nowe propozycje modelowego ujęcia kosztów jakości: A.M. Schneidermana, R S. Kaplana oraz Z. Zymonik. Punkt ciężkości przesunął się z producenta na konsumenta. W centrum zainteresowania znalazł się klient i jego potrzeby, które może on zaspokoić poprzez nabycie produktu spełniającego jego wymagania jakościowe lub realizację usługi najwyższej jakości.

Nowe podejście do jakości rozumianej jako spełnienie wymagań i potrzeb konsumenta znalazło odzwierciedlenie u A.M. Schneidermana, który wykorzystał koncepcję bezbłędności i skoncentrował się na działaniach prewencyjnych.

W teorii R.S. Kaplana rachunek kosztów jakości oparty na działaniach dostarcza informacji, dzięki którym możliwe jest sprawdzenie, czy potencjalne usprawnienia mogą przynieść korzyści lub takie korzyści przyniosły, jak również dlaczego takie korzyści nie zostały osiągnięte (tab. 6).

Tab. 6. Zastosowania rachunku kosztów jakości opartego na działaniach w koncepcji R.S. Kaplana

\begin{tabular}{|l|l|}
\hline \multicolumn{2}{|c|}{ Koncepcja R.S. Kaplana } \\
\hline \multicolumn{1}{|c|}{ podjęte działanie } & \multicolumn{1}{c|}{ skutki } \\
\hline $\begin{array}{l}\text { Użycie rachunku kosztów jakości opartego na } \\
\text { działaniach }\end{array}$ & $\begin{array}{l}\text { Zdobycie informacji o zasobach, które } \\
\text { są niezbędne do realizacji założonego } \\
\text { przedsięwzięcia }\end{array}$ \\
\cline { 1 - 2 } $\begin{array}{l}\text { Sprawdzenie, czy planowane usprawnienia } \\
\text { przyniosą korzyści }\end{array}$ & $\begin{array}{l}\text { Wiedza na temat tego, dlaczego oczekiwane } \\
\text { korzyści nie zostały osiągnięte }\end{array}$ \\
\cline { 1 - 2 } $\begin{array}{l}\text { Sprawdzenie, czy zrealizowane usprawnienia } \\
\text { przyniosły korzyści }\end{array}$ & $\begin{array}{l}\text { Rozważenie opłacalności inwestycji (czy } \\
\text { nakłady się zwrócą? jakie efekty?) }\end{array}$ \\
\cline { 1 - 2 } Analiza kosztów i korzyści &
\end{tabular}

Źródło: opracowanie własne na podstawie Zymonik (2003)

Różnorodność modeli rachunku kosztów jakości (modele strukturalne, modele oparte na działaniach) dostarcza pełnej gamy zastosowań dla różnych typów przedsiębiorstw. Dla firm nastawionych na masową produkcję sprawdza się model A.V. Feigenbauma oraz koncepcja ASQC. Przedsiębiorstwa usługowe wzorce dotyczące rachunku kosztów jakości mogą czerpać z modelu J. Banka. Nowe podejście do jakości prezentuje E. Kindlarski, wyróżniając koszty badania poziomu jakości, które są ważnym elementem pojawiającym się i identyfikowalnym zwłaszcza w podmiotach produkcyjnych. Natomiast modele A.M. Schneidermana i R.S. Kaplana zdecydowanie najlepiej podążają za rozwojem społeczno-gospodarczo-technicznym i doskonale wpasowują się w zapoczątkowaną w ostatnim dwudziestoleciu ubiegłego wieku tendencję do stawiania wymagań klienta i jego potrzeb na szczycie hierarchii działań jakościowych.

\section{Zakończenie}

Do najważniejszych strukturalnych modeli rachunku kosztów jakości należą te zaproponowane przez A.V. Feigenbauma, ASQC, J. Banka oraz E. Kindlarskiego. Niestety dla 
przedsiębiorstw XXI w. są one już nieaktualne i nie uwzględniają postępu naukowego i technicznego.

Model rachunku kosztów jakości oparty na działaniach, autorstwa J.M. Jurana, już z początkiem lat 80 . XX w. przestał być użyteczny. Nowe modelowe rozwiązania A.M. Schneidermana oraz R.S. Kaplana postawiły w centrum uwagi klienta i jego spojrzenie na dany produkt/usługę, dlatego też to one najlepiej sprawdzają się w obecnych czasach.

Problematyka rachunku kosztów jakości przedstawiona w artykule nawiązuje do problemu efektywnego zarządzania kosztami jakości, szeroko dyskutowanego zarówno w literaturze przedmiotu, jak i w praktyce gospodarczej.

Autor postuluje kontynuację badań w zakresie przygotowania nowego modelu rachunku kosztów jakości, który będzie uniwersalnym rozwiązaniem zarówno dla przedsiębiorstw produkcyjnych, jak i usługowych.

\section{Literatura}

References

ASQC (1971). Quality costs: What and how (2nd ed.). Milwaukee WI: ASQC Quality Press.

Bank, J. (1996). Zarządzanie przez jakość. Warszawa: Gebethner i Ska.

Gawron-Zimon, Ł. (2012). Koszty jakości - rozważania teoretyczne. W: T. Sikora, M. Giemza (red.), Praktyka zarządzania jakością w XXI wieku. Kraków: Wydawnictwo Naukowe PTTŻ, 720-727.

Kaplan, R.S. (2001). Strategiczna karta wyników. Jak przełożyć strategię na działania. Warszawa: Wydawnictwo Naukowe PWN.

Kaplan, R.S., Cooper, R. (2000). Zarzadzanie kosztami i efektywnością. Warszawa: Dom Wydawniczy $\mathrm{ABC}$.

Sadkowski, W., Kołodziejczuk, B. (2017). Przegląd klasyfikacji kosztów jakości - ujęcie teoretyczne. Prace Naukowe Uniwersytetu Ekonomicznego we Wrocławiu, 472, 364-375.

Schneiderman, A.M. (2017, 20 września). Optimum Quality Costs and Zero Defects: Are They Contradictory Concepts. Pozyskano z: http://www.schneiderman.com/AMS_publications/ Optimum\%20Quality\%20Costs/optimum.doc

SedevichFons L.A. (2012). Integration of quality cost and accounting practices. The TQM Journal, 24(4), 338-351.

Superville, C.R., Gupta, S. (2001). Issues in modeling, monitoring and managing quality costs. The TQM Magazine, 13(6), 419-424.

Weinstein, L., Vokurka, R.J., Graman, G.A. (2009). Costs of quality and maintenance: Improvement approaches. Total Quality Management, 20(5), 497-507.

Zymonik, Z. (2003). Koszty jakości w zarządzaniu przedsiębiorstwem. Wrocław: Oficyna Wydawnicza Politechniki Wrocławskiej.

Zymonik, Z., Hamrol, A., Grudowski, P. (2013). Zarządzanie jakościq i bezpieczeństwem. Warszawa: Polskie Wydawnictwo Ekonomiczne.

Wojciech Sadkowski, mgr, Uniwersytet Jagielloński, Wydział Zarządzania i Komunikacji Społecznej, Instytut Ekonomii, Finansów i Zarządzania, Katedra Rachunkowości Międzynarodowej. Zainteresowania badawcze: rachunek kosztów jakości, rachunkowość zarządcza, bankowość korporacyjna, sektor małych i średnich przedsiębiorstw, upadłość przedsiębiorstw.

Wojciech Sadkowski, MA, Jagiellonian University, Faculty of Management and Social Communication, Institute of Economics, Finance and Management, Department of International Accounting. Research interests: quality costs calculation, managerial accounting, corporate banking, small and medium enterprises, company bankruptcy. 


\section{Adres/Address:}

Uniwersytet Jagielloński

Wydział Zarządzania i Komunikacji Społecznej

Instytut Ekonomii, Finansów i Zarządzania

Katedra Rachunkowości Międzynarodowej

ul. prof. S. Łojasiewicza 4

30-348 Kraków, Polska

e-mail:wojciech.sadkowski@uj.edu.pl 